\title{
9 \\ Pension Reform in Bolivia: Two Models of Income Security in Old Age
}

Peter Lloyd-Sherlock and Kepa Artaraz ${ }^{1}$

\section{Introduction}

Since the 1980s, two alternative approaches for financing and organizing pensions for older people have emerged across developing regions. These are: (1) contributory schemes, taking the form of capitalized individual accounts, usually managed by private firms; (2) government funded non-contributory "social pensions" provided on either a means-tested or universal basis. Both these approaches are influential in Latin America, where they have often come to replace long-standing defined benefit schemes. Indeed, Chile was a pioneer of the first approach, implementing a reform in 1980 , and it continues to be seen as a model for pension reforms in countries as diverse as Nigeria and India. Since the 1960s, Brazil has developed a substantial social pension programme which runs alongside contributory schemes for protected workers. More recently, social pension programmes have become more widespread in Latin America, including new and enlarged schemes in Mexico, Colombia and Argentina.

In some countries these two approaches have been developed in tandem, comprising two separate "pillars" of an integrated pension system. Theoretically, social pensions can operate as a welfare safety net for people who fail to accumulate sufficient reserves to obtain a decent contributory pension. Bolivia is a case in point. In 1996 the government implemented a combined reform which saw the conversion of existing schemes into privately run capitalization schemes. At the same time, using 
finances from the privatization of state-owned enterprises, the government established a new, universal social pension programme: Bono Solidario (Bonosol). Since that time, Bonosol (and its successor Renta Dignidad) has received considerable international attention and is considered by many to be a model of best practice for pension policy in low income countries (Willmore 2007). Less attention has been paid to the new contributory system, but most evaluations are less than positive about its achievements (Fretes-Cibils et al. 2006).

This paper compares the effectiveness of Bolivia's social pension and its contributory system as tools of income security for older people. We focus on several aspects of their performance: coverage of older people, cost and financial sustainability, administrative efficiency and effects on income distribution. The next section summarizes key elements of the two approaches, reviews international experiences and identifies policy challenges. We then provide some relevant context for the Bolivia case study, before examining the performance of each model. Comparing these distinct approaches within a single country provides important policy lessons, particularly for low-income countries. The chapter draws on a wide range of secondary and grey literature, as well as interviews with key policymakers.

\section{$<$ H1 $>$ Contributory versus Non-contributory Pension Models in Latin America $</ \mathbf{H 1}>$}

Latin America was a pioneer region in the introduction of contributory pension programmes, with funds for a wide range of occupations dating back to before the First World War (Mesa-Lago 1978). Across this region, the middle decades of the 20th century saw continued extensions to pay-as-you-go (PAYG) contributory pension provision for new sectors of the formalized labour force. This was closely associated with economic models of state-led industrialization and the growing 
political leverage of labour unions representing formal sector workers. By the 1980s both the economic model and the model of contributory pension expansion entered a period of prolonged crisis (Mesa-Lago 1989). The failings of Latin America's contributory pension schemes included limited coverage of workers outside the formal sector of the economy and growing indebtedness, due to failures to maintain equilibrium between contributions and liabilities. This financial imbalance had a range of causes, including high rates of evasion, poor returns on investments, corruption, excessive administrative costs and unrealistic entitlements (such as low retirement ages and, in some cases, high pension values). At the same time, government bail-outs made contributory pension schemes highly regressive, redistributing wealth from informal sector workers to the most highly paid formal sector workers. This added to the region's notorious rates of income inequality.

Since the 1980s, most Latin American countries have attempted to implement radical contributory pension reforms. Chile led the way in 1980, obliging new entrants into the workforce to take out pension plans with private fund managers rather than with the state pension scheme (Barrientos 2004a). These new private funds were organized on a fully capitalized basis, thus breaking the financial imbalances of the old state-run schemes. The Chilean reforms were initially viewed as successful, with pension investments generating high rates of return (Vittas and Iglesias 1992). Within a few years, they had inspired a new "Three Pillar" model of pension governance championed by the World Bank, the International Monetary Fund (IMF) and a range of other influential development agencies (World Bank 1994; Charlton and McKinnon 2001).

In much of Latin America, pension privatization and the Three Pillar Model have yielded disappointing results and have attracted much criticism (Müller 2003; 
D’Haeseleer and Berghman 2004). First, it quickly became clear that an effective private pension market requires strong state regulation. There is evidence from a range of developing countries that many private funds charged exorbitant management fees, as well as channelling large amounts of finance into marketing and advertising their products (Dobronogov and Murthi 2005; Riesco 2005). Second, in many countries, rates of return for private pension investments have been erratic, falling short of reformers' optimistic predictions. In recent years, even the World Bank has accepted that the global instability of financial markets, and especially in developing countries, threatens the long-term reliability of returns through a worker's contributory lifespan (Orszag and Stiglitz 2001). This has been manifested during the current global economic crisis, which has led to sharp losses on pension fund investments in developing countries ranging from 8 to 50 per cent in 2008 (World Bank Human Development Network 2009). Third, the loss of younger workers to new private pension funds left state pension schemes with members who were close to retirement or already receiving pensions. Governments were required to directly make up for the lost contributions of younger workers, which meant that public spending on pensions actually rose rather than fell. In Chile, for example, these costs are estimated to have been equivalent to 4 per cent of gross domestic product (GDP) annually between 1980 and 2000 (Edwards 1998). Fourth, claims that greater public faith in the transparency of private management would lead to increased participation have not borne fruit. In many countries, shrinking formal sector employment has led to falls, rather than rises, in pension coverage (Barrientos 2004b) whereas workers in the informal economy rarely contribute to pension funds.

By the start of the 21st century, the credibility of the Three Pillar Model had diminished, although similar reforms were still being discussed or implemented in 
parts of Asia and sub-Saharan Africa. At the same time, a new reform agenda began to emerge, highlighting the potential of non-contributory "social pension" schemes for providing income security for the poorest old people (HelpAge International 2006). Within Latin America, increased attention came to be paid to the Brazilian approach to pension provision. This combines contributory schemes for formal sector workers with a substantial set of social pensions for retired workers and the urban poor.

Studies of Brazil's combined approach claim that it not only reduced poverty among older people, but that benefits were shared across entire households, and could contribute towards family solidarity and improved health and education outcomes (Schwarzer and Querino 2002; Lloyd-Sherlock 2007). In the case of Brazil, entitlements to social pensions and the rural pension depended on claimants' labour history or were means tested. This was to contrast with the model Bolivia has more recently adopted. Here, uniquely in Latin America, non-contributory pensions were to be offered on a universal basis, regardless of labour history or individual economic circumstances.

\section{$<$ H1 $>$ The Bolivian Setting $</$ H1 $>$}

If middle-income countries such as Argentina and Mexico struggled to establish universal contributory pension programmes, the prospects for achieving this in Bolivia have always been remote. Table 9.1 compares a range of development indicators for Bolivia and selected countries from the region. Bolivia remains one of the poorest countries in Latin America, with a small formal labour market (Klein 2003). Poverty is especially concentrated in rural areas (UNDP 2007) and among the country's indigenous population, who according to Bolivia's 2001 census constitute 62 per cent of the population. ${ }^{2}$ According to the Bolivian National Statistics Institute, 
83 per cent of the working population was engaged outside the formal sector in 2007

(INE 2013). The contrasts between Bolivia and richer Latin American countries are less apparent in terms of population ageing. The country's experience of demographic transition has been broadly in line with Brazil and Mexico's, giving rise to similar proportions of populations in older age groups. High rates of poverty, limited economic opportunities and a growing older population increase the need for policies promoting income security in later life. It is claimed that poverty, running at 49 per cent according to ECLAC (2009a), is particularly concentrated among Bolivia's older population, with rates of 59 per cent among people aged 60 and above (Clark 2008). ${ }^{3}$

\section{[Insert Table 9.1]}

Economic instability represents a major challenge to the financial equilibrium of contributory pension programmes. Ideally, funds should be able to achieve reasonably stable rates of return on investments over a period of several decades. During the 1980s, as in much of Latin America, Bolivia experienced a number of severe economic crises. The most serious of these was a hyperinflationary shock in 1984/5. Since 1987, the economy has seen consistent growth, with rates of between 3 and 5 per cent in recent years (World Bank 2013). Theoretically, this sustained economic performance should facilitate the performance of contributory pension financing. The hyperinflationary recession of the mid-1980s was mainly caused by a massive fiscal deficit, a shrinking economy and the country's inability to pay its foreign debt (Green 1995). As elsewhere in Latin America, the crises of the 1980s gave rise to a major reorientation of economic policy, away from state-led protectionism to radical neoliberalism (Grindle 2003). Key elements of the new neoliberal model were privatization of state-owned enterprises and efforts to develop the country's minimal
Commented [CE2]: AQ this work is missing from the Bibliography. We only have INE 2013. Please check and add to bibliography if necessary

KA: Yes, I have changed this to INE 2013. 
financial markets. Contributory pension reform was viewed as an essential part of this strategy, although it was only introduced in the mid-1990s.

Despite generating stable economic growth, the social achievements of the neo-liberal model were very limited, as reflected in enduring rates of poverty and limited formal employment opportunities. By the late 1990s, popular political opposition to the ruling regime started to gather pace, partly fuelled by mounting evidence of widespread corruption and a generalized disenchantment with formal party politics dominated by ruling oligarchies that shared the spoils of power through political patronage (Gamarra and Malloy 1995). This popular resistance included several high-profile rebellions across rural and urban areas, with increased political activism among indigenous groups and coca leaf growers led by one Evo Morales (Crabtree 2005). In 2005 these currents of opposition led to a dramatic political shift; the election of Evo Morales as leader of the left-wing pro-indigenous Movement Towards Socialism (MAS). The following years have seen a series of political crises, including regional conflicts over taxation and control of natural resources. In 2009 a new national constitution was agreed, and this contained a range of universal welfare guarantees, including universal pensions for older people. Despite Morales's anticapitalist ideology and the current global crisis, the Bolivian economy has continued to grow by 5.2 per cent in 2012 (World Bank 2013). In large part, this has been due to the exploitation of new large gas deposits, which has generated large amounts of public revenue through tax and royalties (Catena and Navajas 2006).

\section{$<\mathrm{H} 2>$ Contributory pensions in Bolivia $</ \mathrm{H} 2>$}

Bolivia's contributory pension schemes were established later than in most other countries in the region, and on a more limited basis. In 1957, with the support of the 
International Labour Organization (ILO), a number of small funds were brought together into a single state-run national pension programme. As elsewhere in Latin America, this programme was financed on a PAYG basis. However, one unusual feature was that unions and other professional groups were permitted to set up parallel, voluntary "complementary pension funds". These resembled the Third Pillar of the World Bank model, although workers were not allowed to choose their complementary fund. Together, these programmes only covered around 11 per cent of the workforce by the mid-1990s (Escobar and Nina 2004).

By the 1980s, both the main state fund and the top-up complementary ones had begun to register substantial deficits. Pension values were fixed (defined benefit), irrespective of variations in contributions, and the retirement age was just 55 for men and 50 for women. ${ }^{4}$ By the 1980 s, growing numbers of affiliates were reaching retirement, so that the ratio of contributors to beneficiaries fell sharply: from 5.2 to 2.7 between 1980 and 1995. Even then, a high proportion of contributors, both workers and employers, evaded payments, and little was done to police this. Finally, the pension funds levied excessively high administrative costs, averaging 17 per cent of total contributions, and it is alleged that the system suffered from widespread corruption (von Gersdorff 1997). For example, one complementary fund had invested substantial amounts in a loss-making nightclub that provided free entertainment to its own managers (Revollo 2004). By the mid-1990s, the government was regularly bailing out the state pension system at average rates equivalent to 1 per cent of GDP a year. It was also making substantial discretionary payments to the complementary funds. As the numbers of beneficiaries continued to grow, it was clear that these deficits would rapidly worsen. 
Pension reform was a high priority for the neo-liberal regime that took power in 1985. It was seen as a key tool for regaining control of public finances, reducing labour costs and developing financial institutions. At the same time, international financial institutions exerted considerable pressure for reform (Kohl and Farthing 2009). Despite this, there was a delay of several years before changes were implemented, due to sustained resistance from labour unions and public sector workers (Müller 2008). It was necessary to set up a new government department, a Ministry of Capitalization and Pension Reform, which was allowed to operate independently of the pro-union Ministry of Labour (Revollo 2004). The contributory pension reform was finally enacted in 1996. The state scheme and complementary funds were completely replaced with immediate effect by a new fully capitalized programme financed entirely by workers' contributions. ${ }^{5}$ According to one of the reform's designers, "the vision was clear: leave poverty behind, by attracting large capital investments, creating internal savings" (Revollo 2004: 8).

It was planned that the new pension system would initially be run by just two private sector organizations, selected through a process of international bidding. ${ }^{6}$ Limiting the number of operators was justified in terms of the small size of the potential pension market and a need to limit marketing costs. Despite the neo-liberal tenor of the reform, competition was to be phased in slowly. Each firm was allocated monopoly rights for one of two geographical areas with equal populations. By 2000 affiliates would be entitled to move between these funds, and in 2004 new firms would be allowed to enter the market. In fact, there is little evidence that meaningful competition has developed. The products offered by each fund are very similar, few affiliates ever opt to switch and no new firms had been established by $2009 .^{7}$ 
Like most other Latin American countries, the Bolivian reform of 1996 was strongly influenced by Chile's pension privatization. There were, however, a number of features that made the Bolivian case stand out. Most other countries had implemented a "softer" version of the Chilean model, making greater provision for state participation and minimum pension guarantees. By contrast, two aspects of the Bolivian reform could be considered to be a more radical version than the Chilean model. First, the old pension funds were completely and immediately replaced by the new system, forcing all workers out of the PAYG system and into a capitalized one of individual saving accounts. Second, there was no minimum pension guarantee.

The Chilean reform had permitted workers who were already affiliated to pension funds to remain within the old system. This meant there was a transition period between the old system being phased out and the new competing funds taking over the entire industry. In Bolivia there was no such transition, and even affiliates nearing retirement were obliged to join one of the private schemes. As a result, the old state and complementary funds were left with large numbers of pensioners, but no contributions, and government was required to fill this financial shortfall. The government was also required to transfer capital to the private funds to cover the contributions that affiliates had already made to the old schemes. ${ }^{8}$ Due to the low coverage of the old schemes, it was projected that these costs would be no higher than 2.6 per cent of GDP (Revilla 2002). However, they had already reached 5 per cent of GDP by 2002. Among other causes, this was due to a decision to substantially increase the real value of pensions being paid out by the old system. Interestingly, this level of deficit was roughly equivalent to the projected costs of the unreformed system by 2002 . 
At the same time, the new private pension operators received substantial indirect state subsidies in the form of above market rate returns on government bonds. The limited development of Bolivia's capital markets meant that there were few options for investing pension finances locally. To reduce overseas investments, the two funds were required to invest at least 65 per cent of their portfolios in treasury bonds. These generated guaranteed rates of return of 11 per cent a year between 1997 and 2002, making the new pension industry a highly lucrative monopoly (Arze Vargas 2009). In later years, rates on government bonds were cut, but they continued to offer very generous terms. By July 2010, the combined assets of the two Administradoras de Fondos de Pensiones (AFPs) (private pension funds) were equivalent to over US\$5 billion. The AFPs claimed that their rate of commission (set at 0.5 per cent of affiliates' salaries) was substantially lower than most other pension systems in Latin America (Interview with the AFP Previsión Fund manager, July 2010). However, this does not include other fees. For example, AFPs charged 1.3 per cent of each monthly pension payment to beneficiaries as well as separate fees to government for the administration of pension funds. This was on top of other charges such as a varying percentage of each worker's contribution to professional and health insurance (Interview with General Director of Pensions, Bolivian Vice-Ministry of Pensions, July 2010).

The 1996 pension reform included important changes to pension entitlements. The standard age of retirement was raised to 65 for men and 60 for women. Expectations at the time of its introduction were that affiliates would be able to accumulate sufficient savings to allow for a minimum lifetime pension equivalent to 70 per cent of the minimum monthly wage. The reality, however, is that many affiliates did not reach this savings threshold for a number of reasons, including 
labour market instability that led to interruptions in employment and hence to interruptions in contributions. This is the reason why many formal sector workers such as teachers delayed retirement. In the case workers did not accumulate sufficient funds to finance a life-long minimum pension, the AFPs provided a minimum monthly payment equivalent to 70 per cent of the minimum wage but only until the insured's accumulated funds in the individual account were exhausted..$^{9}$ Once these savings were depleted, the pension was completely discontinued. As a result, pensioners faced a growing risk of suddenly losing benefits the longer they survived past 65 , increasing the economic vulnerability of people in the oldest age categories. The only exceptions to this system were the military and senior members of the judiciary, who were given explicit guarantees that their previous generous pension benefits would not be reduced (Escobar and Nina 2004).

It was predicted that the new pension programmes would be paying out at least 45,000 benefits by 2007, but the actual number was only 12,000 (Arze Vargas 2009). In part this was due to the difficulty of satisfying the stringent retirement requirements. Also, large numbers of members had opted to delay retirement because the value of the capitalized annuity was substantially lower than their current salaries. ${ }^{10}$

At the same time, the reformed system had performed poorly in terms of extending coverage by increasing affiliation. By 2002 coverage was roughly 11 per cent of the economically active population, which was no higher than that achieved by the old schemes. As a result, only 15 per cent of the population aged 65 and over currently receives a contributory pension of any kind. Fund membership is concentrated among higher-paid formal sector workers, with coverage of less than 3 per cent for the rural population. Table 9.2 shows levels of inclusion by educational 
status and income quintile. Only 0.5 per cent of the poorest 20 per cent of Bolivians were included in the new system. Even among the richest quintile of the population, the pension uptake is no higher than 30 per cent. This inability to attract more than 30 per cent of people in the richest income quintile (for whom contributions would have been affordable) demonstrates the failure of the private firms to develop the pension market.

\section{[Insert Table 9.2]}

Given the concentration of coverage among the rich, and the heavy levels of direct and indirect government subsidy, it is evident that the capitalized pension system was highly regressive, distributing public spending away from poorer socioeconomic groups. Meaningful competition between private administrators has never been introduced, investments remained highly concentrated in treasury bonds and the prospects of the new scheme providing lasting income security to substantial numbers of pensioners was questionable. According to the World Bank, the failures of Bolivia's reformed contributory system are mainly due to poor implementation, rather than shortcomings of policy design (Fretes-Cibils et al. 2006). Yet it is difficult to envisage how a capitalized contributory system could be made to work in the Bolivian context. Indeed, studies of other Latin American countries have reached similar conclusions (Mesa-Lago 2004; Arza 2008).

Predictably, renationalizing the contributory pension programme featured prominently in MAS's 2005 election campaign. Progress towards reform was initially slow, however, and it was not until late 2008 that a new pension law was approved by Congress, although it was never approved by a Senate that remained controlled by the opposition during the first government of Evo Morales (2006-9). Despite MAS's radical ideological agenda, this law sought to modify the existing pension scheme, 
rather than completely replace it. Its main proposals were that the pension age be reduced to 60 , that new private administrators and competition be introduced and permitted to operate for no more than ten years and that regulation be strengthened (La Prensa 2008). ${ }^{11}$ Perhaps surprisingly - given the government's radical rhetoric no provisions were made for reintroducing employer contributions nor for the state to take over running the pension schemes, in spite of serious lobbying from the trade unions' congress, the Central Obrera Boliviana (COB) and NGOs such as the Centro de Estudios para el Desarrollo Laboral y Agrario (CEDLA) (Labour and Agricultural Development Centre).

Following MAS's landslide victory in the December 2009 general election, a more radical pension reform was proposed. This bill was ratified by the new plurinational assembly that replaced Congress with the implementation of the new constitution. It was also ratified by the Senate in December 2010 and implementation started in 2011. The new pension law (Law No. 65), stipulates that the national government completely take over contributory pension fund administration from the AFPs (Mendoza, 2013). The retirement age was set at 58 for men and between 55 and 58 for women (VPSF 2010). ${ }^{12}$ The new scheme includes a Solidarity Component, which seeks to guarantee a minimum pension value for anyone who has made at least ten years' worth of contributions. The calculation of the minimum pension uses sliding scales to take into account the total years and amounts of contributions. For affiliates with 30 years of contributions, this may be as high as 70 per cent of their average salary in the last two years of work. ${ }^{13}$ It is claimed that over 80 per cent of contributory affiliates will gain as a result of this scheme (Interview with the General Director of Pensions, Bolivian Vice-Ministry of Pensions, July 2010). 
The costs of these guaranteed pensions will be met by the Solidarity

Component. The solidarity fund will be created from a number of sources. As Table 9.3 shows, there will be an additional contribution from workers ( 0.5 per cent). In addition, the new law introduces employer contributions at 3 per cent. On top of that, the solidarity fund will receive 20 per cent of the contribution made by workers towards accident insurance (around 1.71 per cent of their monthly salary in the private AFPs.) Finally, a variable contribution from the most highly paid workers has been introduced on a sliding scale, whereby those with salaries equivalent to 20 or more minimum wages pay 1 per cent of the excess, those with 40 or more pay 5 per cent, and those with salaries equivalent to 60 or more minimum wages (around US $\$ 6,000$ per month), pay 10 per cent to the solidarity fund. The value of the minimum pensions will be open to revision every five years. Table 9.3 also shows the relative weight of each of these four contributions to the solidarity fund, which is expected to reach US\$140 million per year and represents an important redistributive component of the new pension system.

\section{[Insert Table 9.3]}

It is argued that the reform will promote equity within the contributory system, by redistributing resources to workers on low pay and to women with several children (Guillén 2010). Introducing a minimum pension guarantee will also bring the Bolivian contributory system closer into line with pension programmes elsewhere in Latin America. Renationalizing the contributory pension system is part of a wider trend in the region, including a high-profile reform in Argentina (see Hujo and Rulli in this volume).

The current reform aims to transform the contributory pension system and do away with most of the key elements of the original neo-liberal reform. However, the 
new system will remain very different to the one that operated before 1996. Pension financing will still operate on a capitalized model (albeit with a large solidarity element), employer contributions will be considerably lower ( 3 per cent compared to 5.5 per cent) and the state will be exempt from any direct contributions (except as an employer for civil servants). In sum, the new Bolivian contributory system aims to reintroduce the state into the management of pension funds on a not-for-profit basis. This however, does not alter the capitalized nature of the pension model.

Despite the new sources of revenue, the financial sustainability of the new system has been called into question. Since the value of pensions generated by the capitalized system has typically been equivalent to a replacement rate of 30 to 40 per cent, the level of funding needed to bring these up to the guaranteed minimum pension will be very substantial. The capacity to capture contributions from very high earners (either as tax or social insurance contributions) has also been historically very limited. It is also possible that employers will reduce their contribution liabilities by taking advantage of legislation that facilitates subcontracting, with subcontractors not being obliged to provide social protection coverage (Interview with CEDLA Senior Researcher in August 2010). In the face of these financial pressures, it is possible that the value of the minimum pension guarantee will be substantially reduced over time.

\section{$<$ H2 $>$ Non-contributory pensions in Bolivia $</ \mathrm{H} 2>$}

As part of the 1996 pension reform, Bolivia introduced a universal non-contributory scheme, Bonosol, to run alongside the new contributory funds. Rather than a monthly pension, Bonosol paid out an annual sum equivalent to US\$248 to everyone aged 65 years old or more. The scheme was to be financed from the proceeds of privatization of state enterprises. ${ }^{14}$ As such, it played an important political function in reducing 
opposition to a wider programme of neo-liberal reform. The revenue generated by these privatizations (around US\$41.7 billion) was placed in Collective Capitalization Funds (CCFs). These funds were entirely separate from the fully funded contributory pension accounts. Despite this, the same two private firms invited to manage the contributory scheme were brought in to manage the CCFs' assets. ${ }^{15}$

It was initially claimed that effective investment of the CCF funds would generate sufficient returns for Bonosol to become largely self-funded. This would permit annual payments to remain at US\$248 for the first five years of the scheme, with revisions for further years. In fact, Bonosol only operated in its original form for a single year. There were two main reasons for its short lifespan. First, the CCF funds were insufficient to meet the full costs of the annual payments. In large part, this was because the legal procedures for conducting the sale of part of the capitalized companies to the private sector had not been completed before the presidential elections of 1997 , forcing the fund managers to take out a US $\$ 45$ million loan to cover the gap (Martínez 2004). Second, 1997 saw a change of political leadership in Bolivia, and the incoming administration preferred to be associated with a new programme. Between 1997 and 2000, Bonosol was suspended and was then replaced by a downgraded scheme known as the Bolivida. Under this new scheme, benefits were cut to US\$60 a year, although back payments were made to cover the missing years of 1998 to 1999 (Molina 2007). The Bolivida was to be completely funded from the interest earned by the privately managed $\mathrm{CCF}$, but, as with the contributory funds, this interest largely came from over-market rates of return on government bonds. As such, the scheme was essentially being funded by government, which also paid private firms a commission for running it. 
The Bolivida lasted little longer than the original Bonosol. In 2002, following a further change of political leadership, the Bonosol was reinstated, with the benefit restored to US\$248 a year (Müller 2008). It was claimed that these more generous benefits would be financed by the sale of shares in the CCFs, which would raise around US\$90 million a year (Martínez 2004). The election of Evo Morales in 2005 led to a re-evaluation of the Bonosol, and in 2008 it was replaced by yet another variant: Renta Dignidad.

Renta Dignidad is a universal social pension that offers more generous benefits than those offered by its forebears. First, the age of entitlement has been reduced from 65 to just 60 years old, representing an additional 226,000 beneficiaries. Second, the value was increased to US\$340 for people who lacked a contributory pension and US $\$ 257$ for those who had one. ${ }^{16}$ It was estimated that this upgraded scheme would cost around US\$190 million a year, considerably more than the rates of return generated by the CCF investments (only around US\$25 million a year). By 2008, the projected annual cost of Renta Dignidad was increased to US\$260 million. The reasons for this substantial rise include a proposed increase in benefit values, a higher exchange rate for the Bolivian currency, and extra administration costs incurred in improving payment mechanisms. Most of this substantial shortfall is funded by a new local government hydrocarbons tax, along with general taxation and profits from nationalized companies (Ministerio de Economía y Finanzas Públicas2009). High prices for export commodities and discoveries of new hydrocarbons have rapidly increased this source of tax revenue and reduced political resistance from local governments (ECLAC 2009b). Despite its increasing cost, Renta Dignidad still represents less than 2 per cent of GDP: considerably less than direct and indirect government support for the contributory pension system. 
By 2005, 676,000 Bolivians were aged 60 or over and were entitled to a Renta Dignidad benefit. Data from the National Pensions Office for 2008 indicates that over 700,000 people received payments, and this figure climbed to 830,000 by 2012 (Quispe 2013). Some opposition political groups have alleged that there are many fraudulent claims, although this has not affected the popularity of Renta Dignidad. A more practical problem for eligible claimants, especially in the rural areas, is their lack of identity cards, which makes it impossible for them to receive their social pension. In 2006, MAS implemented a large programme of enrolment in rural areas to maximize access to this benefit, but this programme was superseded in 2009 by the introduction of a new biometric fingerprint identification system in time for the December presidential elections that, it is claimed, will also help curb fraudulent pension claims. In spite of progress towards making Renta Dignidad a truly universal pension, local NGOs estimate that around 10 per cent of eligible people still lack identity documents and are therefore excluded from the programme, especially in rural areas and among monolingual Quechua and Aymara speakers. ${ }^{17}$ More generally, considerable efforts have been made to facilitate access to Renta Dignidad payment centres. Instead of annually, the benefit can now be collected at more regular intervals, such as on a monthly basis. Under the previous schemes, this had represented a major challenge for older people living in more remote rural areas. Since the introduction of Renta Dignidad, the government has enlisted the army to travel to the people instead and to distribute the benefit in rural areas, including the establishment of local telephone and banking services (Cedib 2008).

It is striking that even the small proportion of older people who receive generous contributory pensions are also entitled to Renta Dignidad. On one hand, this may be seen as further support to an already privileged group. On the other, these 
payments ensure that Renta Dignidad can be portrayed as a truly universal benefit, rather than a means-tested one. This is useful for several reasons. First, means testing would run counter to the socialist ideology of the current regime. Second, these payments may theoretically give politically influential higher income groups a sense that they also have a stake in the Renta Dignidad programme and increase their support for its continuity as well as for other changes in social policies currently being introduced by the MAS government. ${ }^{18}$ Third, it might be argued that administering the process of eligibility might have been relatively expensive. However, it could be argued that the introduction of Renta Dignidad on a universal basis rests on the implicit acknowledgement of the failings of a contributory system that delivers very small pensions to the majority of this select group of beneficiaries.

It is to be expected that by providing large numbers of older people with a reliable income stream, Renta Dignidad does much to promote economic security and well-being in later life. The value of the Renta Dignidad payment is now over US\$1 a day for those who have no access to contributory pensions, and is therefore just enough to lift individual beneficiaries with no other sources of income over the official poverty line. However, there is considerable evidence from Bolivia and other developing countries that many older people are expected to share this benefit with other household members, especially where other income sources are scarce (Skinner 2007; Clark 2008; Mejia Bastos and Dusseau 2008). On one hand, this may dilute the impact of the scheme on older individuals; on the other, it may be seen as spreading the benefits of Renta Dignidad across a larger section of the population: it is estimated that around a quarter of households contain a beneficiary (Skinner 2007). The experiences of many developing countries demonstrate the many difficulties of targeting social transfers, leading some to argue that universal social policies have a 
better long-term effect than targeted ones in establishing social protection for all and in promoting inclusive development (Mkandawire 2005). In the case of Renta Dignidad, its benefits arguably go beyond poverty reduction. According to Skinner (2007), Renta Dignidad increases the visibility and participation of the poorest older people as full citizens and reinforces the intergenerational social contract.

\section{$<\mathrm{H} 1>$ Comparing the Two Systems $</ \mathrm{H} 1>$}

The Bolivian experience since 1996 clearly illustrates the respective capacity of contributory and non-contributory pension schemes to deliver income security to older people in low income countries. Put simply, it demonstrates that noncontributory social pensions are much better suited to this task. By 2007, the contributory system paid out pensions to around 65,000 older people, of which only 12,000 were paid by the new private scheme. In $2004-5$, this contributory system absorbed around 5 per cent GDP in government subsidies, not including substantial indirect subsidies of up to 40 per cent of the annual transition costs through treasury bonds (Meléndez Howell and Alejandro Soto 2004). The high transition cost reflects the costs of switching from a PAYG to a funded system, and ultimately the ability of politically influential groups of relatively privileged workers to retain generous pension values paid out through the pre-reform system. This increases transition costs and hence outstanding government liabilities. By contrast, the social pension pays out over 830,000 benefits at a cost of less than 2 per cent of GDP. At the same time, it is to be expected that the social pension will significantly contribute to reducing poverty. Since it is not means tested, Renta Dignidad's impact on income distribution will be less obvious. In recent years, Bolivia's income distribution has improved, although it still remains very unequal by international standards. For example, 
between 1999 and 2009, the share of national income held by the poorest two quintiles rose from 1.2 to 2.6 per cent (ECLAC 2013). The causes of this improvement are complex and, as in other Latin American countries, the relative contribution of cash transfers should not be overstated (Bertranou and Maurizio, 2010). Nevertheless, high levels of poverty among older age groups suggest that the scheme will potentially improve the national distribution of wealth. ${ }^{19}$ For its part, the contributory system fails to reach poorer groups and leads to substantial redistribution of wealth towards the better off. The new reform will reduce inequality within those groups included in the contributory system, but will still lead to a redistribution of wealth from non-insured to insured groups (through state contributions for civil servants and by less direct forms of subsidization).

For both schemes, financial sustainability fundamentally depends on the availability of public finance and the wider health of Bolivia's economy. The Pensions Vice-Minister himself recognized that the sustainability of the pensions system as a whole is heavily dependent on future oil and gas revenues (Interview with the Bolivian Vice-Minister of Pensions, August 2010).

In 2007 and 2008 tax receipts continued to grow rapidly, reaching an annual rate of 33 per cent of GDP (compared with an average of 19 per cent for Latin America and the Caribbean) (ECLAC 2009b). The global crisis of 2008/9 caused a sharp fall in these receipts, and this led to a decision to postpone a small increase in the benefit, which lasted until 2013 when Renta Dignidad was increased by a flat Bs50 per month. ${ }^{20}$ It was projected that gas and oil tax receipts and royalties would fall by around 17 per cent in 2009 . In the event, according to official figures, income from hydrocarbons has increased steadily, and is projected to reach US $\$ 1,688$ million in 2011 (Hidrocarburos Bolivia 2011). The central bank has been able to accumulate 
substantial foreign reserves worth US\$7.8 billion in 2008. Although fears existed that these may quickly be depleted if the wider economic situation did not improve, Bolivian GDP growth in 2009 was 3.4 per cent and foreign reserves increased to US\$8.58 billion (ECLAC 2010a), rising to 5.2 per cent and 11.66 billion in 2012 (World Bank 2013). This means that the Morales administration has not been forced to be more selective about its public spending priorities than it has been in the past, nor has it been forced into making politically costly trade-offs between contributory and non-contributory pensions.

It is interesting to consider whether it is valid to portray the two pension schemes as fundamentally independent or as part of a single system. Both programmes were established by the same legislation in 1996, both were run by the same private contractors for a number of years and since the 2010 Pensions Law both are planned to be administered again by the state as part of a single system. In addition, both are heavily dependent on financial support from the state. In political terms, there were important links between Bonosol and the contributory pension reform, since the former was used to justify the lack of pension guarantee in the latter. More generally, by including Bonosol's creation and the 1996 contributory pension reform in a single bill, the government sought to reduce opposition to pension privatization. According to Katharina Müller, "the Bonosol scheme was primarily designed to complicate opposition to pension privatization" (Müller 2008: 165). It could therefore be argued that they form elements of a single two-pillar pension scheme, whereby the non-contributory safety net compensates for the lack of a guaranteed pension from the contributory pillar. While the 2010 reform was essentially targeted at the contributory scheme, it is referred to as a new Integrated Pension System (Sistema Integral de Pensiones, SIP), which includes the contributory 
scheme, a semi contributory solidarity element and a non-contributory universal pension (VPSF 2010). This is the reason why the government extols the virtues of the new system in terms of the solidarity transfer it provides from the richest to the poorest workers. In addition, this system aims to increase the coverage of the contributory system by opening it up and making it attractive to the self-employed, who can receive a modest pension with ten years of contributions.

Nevertheless, there are good reasons for viewing these schemes as essentially separate. First, the flow of funds between the capitalized accounts and the noncontributory system is limited. Second, there is little overlap between them in terms of their fundamental welfare and political objectives. The contributory pension scheme is mainly concerned with maintaining the political support of powerful groups of workers, with the development of local capital markets a secondary objective and old age income security barely registering as a third consideration. By contrast, Renta Dignidad is first and foremost a pro-poor welfare initiative, which also seeks to create a new social contract between more marginalized social groups and the state. As part of this, the two systems follow a different political logic. The contributory system has a long history and entrenched interests that guarantee its survival. By contrast, the universal pillar is the result of more recent political processes linked to legitimizing privatization (in the case of Bonosol) or tackling poverty and fostering social inclusion (in the case of Renta Dignidad). Whether this social contract survives the vicissitudes of the global economy remains very much to be seen.

In sum, Bolivia has made steady progress in the provision of income security in old age through two types of provision - one contributory, the other noncontributory - that were introduced in 1996 for very different purposes and obeying different priorities. The former followed neo-liberal reforms in the region that sought 
to encourage the individualization of responsibility for financing old age pensions through a capitalized system that was supposed to free the state from funding obligations. In the event, state direct and indirect subsidies increased in the period following the introduction of this pension system. In the case of the non-contributory pension, a neo-liberal logic was also at play because it was provided as a sweetener in exchange for the privatization of state monopolies. Moreover, state commitment to the non-contributory pension between 1996 and 2005 was inconsistent.

The arrival to power of MAS at the end of 2005 led to a complex period of policy reform that has been gradually implemented since 2011 . The new regime immediately established a new universal non-contributory pension scheme, Renta Dignidad, which was upgraded in terms of its reach and value of the benefit. Reform of the contributory system has been more complex, but was finally passed into law in 2010. In spite of demands from trade unions, the government has maintained the capitalized nature of this system, which has been in place since 1996. However, it has introduced a redistributive ‘solidarity' element within contributory pensions and plans to increase the uptake of this type of pension among the self-employed, increasingly referring to both systems as part of an integrated whole.

The most obvious lesson for other developing countries is that noncontributory social pensions are a much more efficient means of meeting the welfare needs of older people than contributory schemes. Despite this, contributory pension schemes for privileged workers such as civil servants are ubiquitous, whereas large social pension schemes are few and far between. In countries where both exist, government spending on social pensions is usually a fraction of spending on contributory ones. The Bolivian experience also shows that contributory pension funds create powerful vested interests among privileged groups of workers who can 
resist substantial reforms, even under radical non-elite governments. Only six years after Morales took office was the contributory system meaningfully modified, although many of its essential features remain. Similarly, Lula in Brazil was able to make little headway in reforming that country's costly and inequitable contributory pension system (see Chapter 5 in this volume). Both Bolivia and Brazil have benefited from increased fiscal resources which enabled the extension of social pensions without threatening the vested interests of the contributory system. In many developing countries, the scope to do this is limited.

\section{$<$ H1 $>$ Notes $</$ H1 $>$}

${ }^{1}$ The authors would like to thank Gabriela Barriga from the Corporación Minera de Bolivia (COMIBOL), James Blackburn from HelpAge and Lola Paredes from Fundación Xavier Albó for their help in locating key sources of information, without which this article would not have been possible. ${ }^{2}$ The figure of 62 per cent indigenous population is widely used in Bolivia by a government that presents itself as a government of the "indigenous majority". The figure emerged from the 2001 census that included a question on ethnic self-designation. This issue has caused much debate in a country where some argue that there is no basis for declaring that Bolivians constitute anything other than a single mestizo group (Toranzo Roca 2008), whereas others argue that the ethnic and cultural "blindness" that characterized the country's birth, and even the 1952 revolution, are responsible for the historical exclusion of the indigenous majority (Albó 2008).

${ }^{3}$ Poverty figures in Latin America show large variations depending on the measurement methodologies employed by the different international organizations such as the World Bank (WB) and the Economic Commission for Latin America and the Caribbean (ECLAC). In the case of Bolivia, moderate poverty ranges from 42.8 to 63.9 for 2004 . In the case of extreme poverty, the figures are 23.9 and 34.7 per cen of the population respectively. See Helwege and Birch (2007). However, there seems to be agreement on the fact that Bolivia has seen a reduction in poverty in the last ten years (León 2008).

${ }^{4}$ The state pension promised pensions of around 30 per cent of a member's last five years' salary; the complementary funds offered 40 per cent. The early age of eligibility of benefits has to be understood in the context of a country with the second lowest life expectancy in Latin America and the Caribbean, which in 2010 was still 67 years (ECLAC 2013).

${ }^{5}$ Employers do make a 2 per cent contribution to a separate scheme for worker accident compensation. This compares to a 12.5 per cent contribution levied directly on workers.

${ }^{6}$ The two successful bidders were Invesco-Argentaria (Spain) and Banco Bilbao Vizcaya (BBV) (Spain). In 2000 BBV bought Invesco Argentaria and is now known as Banco Bilbao Vizcaya Argentaria (BBVA), which was required to sell its Bolivia pension operation to Zurich Financial Services. In Bolivia, they created pension funds known as AFP Previsión (that belongs to BBVA) and AFP Futuro (owned by the Zurich group).

7 The first MAS government's 2008 new pension proposal was passed by Congress but never approved by a Senate that was in the hands of the opposition. That proposal made provision for the involvement of additional private firms in the administration of pension funds to deliver effective competition to the existing AFPs. However, since the resounding victory of MAS in December 2009, a new pension law was approved by the new plurinational assembly (Congress) and the Senate in 2010 that effectively removes private AFPs in favour of a single state administrator. The transition was originally planned to take place in the course of 2011, as established by the new Pensions Law. By 2013 this had not yet taken place, partly due to the opposition of the trade unions (Xinhua 2013). 
${ }^{8}$ The old pay-as-you-go (PAYG) system entered into a period of financial problems due to poor administration, demographic changes and fraud. Eventually the state had to subsidize it and, by the time the system was transformed into its capitalized form in 1996, the pension system had funds for less than six months. The state now compensates individuals who contributed to the old system but are retiring in the new one. Projections estimate that state contributions will peak in around 2025 and then decline rapidly until the death of the last pensioner who requires compensation for contributions to the pre 1996 system (Interview with the Bolivian Vice-Minister of Pensions, August 2010).

${ }_{9}^{9}$ Those who had not made enough contributions to cover the costs of a pension worth at least 70 per cent of the minimum wage for the rest of their lives if they retired at 60 or 65 would be paid a pension worth 70 per cent of the minimum wage until the money in their personal fund had run out. This was based on their actual contributions plus interest to the new capitalized regime, along with a notional value allocated to the contributions they had made to the pre-1996 PAYG regime. Because they received nothing from the contributory system, many people who found themselves in this position (especially women, who had had more interruptions to their working lives and who were meant to retire at 60) would delay retirement.

${ }^{10}$ For example, the Bolivian Vice-President of Pensions and Financial Services claimed that 10,000 school teachers had to postpone their retirement since the value of their pensions would only be around a third of their salaries (Lazcano 2010).

${ }^{11}$ The regulatory framework in the 2008 pension proposal permitted state intervention where capital loss in pension funds reached 20 per cent.

12 The retirement age for women will depend on the number of children they have. It will be one year less than 58 for each child up to a maximum of three. Special workers' groups such as miners are to be offered lower retirement ages (between 51 and 56 years old) and a more generous scale of pension values. It is claimed that few miners reach the retirement age and most receive disability pensions at younger ages.

${ }^{13}$ The reform proposes fixed replacement rates (relative to average salaries for the two years previous to retirement) of between 56 and 70 per cent for people who contributed for between 16 and 35 years. There will be a fixed minimum benefit (currently set at US\$187 a month for those with 35 years of contributions) as well as a maximum ceiling (US\$345 a month). For people with between ten and 20 years of contributions there will no fixed replacement rate, but they will be offered a guaranteed benefit value ranging from about US\$68 to US\$96 month. These amounts will be revised every five years.

${ }^{14}$ Half the sale value of these state enterprises was sold to private investors and the funds generated by this sale was placed under the management of private fund managers.

${ }^{15}$ These firms charge a commission for managing their total portfolios made of the contributory pension capitalization account as well as the Collective Capitalization Fund. These commission rates are set on a sliding scale that depends on the size of the combined size of the accounts and range between 0.2285 per cent for accounts up to US $\$ 1,000$ million to 0.0067 per cent for accounts between US\$1,200 and 1,500 million, with no commission thereafter (AIOS 2003).

16 This corresponded with a monthly benefit of Bs200 and 150 respectively. In May 2013 a flat increase of Bs50 was introduced for all. At the current rate of exchange, this corresponds to an annual pension of around US\$430 and US\$340 respectively (Quispe 2013).

${ }^{17}$ This is difficult to quantify. A study by Skinner (2007) in two neighbourhoods of La Paz showed that lack of access to Bonosol, the predecessor to Renta Dignidad, was even higher, at around 20 per cent ${ }^{18}$ The argument that universal benefits received by high-income earners will be channelled back into the state budget via personal income tax mechanisms does not apply to Bolivia, where this tax does not exist.

${ }^{19}$ Official figures from the Bolivian Office of National Statistics show that extreme poverty decreased between 2000 and 2009 from 45 to 26.6 per cent. The Gini index also shows a reduction in inequality: from 63 in 2000 to 50 in 2009 . The introduction of the universal social pension almost certainly contributed to this reduction, although there have been other, smaller and targeted transfers introduced for schoolchildren and for new mothers. It is thought that rapid economic growth, increased employment and the introduction of minimum wages have also contributed to reduced poverty and inequality (León 2008; INE 2013).

${ }^{20}$ Since Bolivia experienced an annual inflation rate of over 11 per cent in 2007 and 2008 , the failure to increase the value of the Renta Dignidad benefit represented a significant reduction in its real value. Inflation fell to 4.5 per cent by 2012 (World Bank 2013). 